\title{
Impact Sainspreneur to Build Students Self-sufficiency and Creativity of Elementary School Students
}

\author{
Wita Cholifah ${ }^{1}$, Ristiana Dyah Purwandari ${ }^{2}$ \\ \{ withacholifah@gmail.com ${ }^{1}$, ristianadyah@yahoo.com $\left.{ }^{2}\right\}$ \\ ${ }^{1,2}$ Universitas Muhammadiyah Purwokerto
}

\begin{abstract}
The 2013 Curriculum has the goal of creating Indonesian people productive, creative, innovative, through enhanced attitudes, knowledge, and integrated skills. To build an effective, creative, innovative, and knowlegeable human being requires innovation in learning by combining two skills called science and entrepreneur. Sainspreneurship is an ability to manage science and science skills to be used and enhanced more optimally to improve living conditions for the future. Science studies combined with preneur or something called Sainspreneur. Its application through urban settlements is a system-based environmental food defense strategy. The purpose of this study was to provide students with life skills application of Sainspreneur through urban farming techniques to build self-sufficiency and creativity of students in elementary schools. The method used in this research is the literature study method. The data obtained were compiled, analyzed, and concluded to get conclusions about the literature study. Based on the research results, literature studies from several research results and journal articles show that the use of application Sainspreneur with urban farming techniques can build self-sufficiency and creativity of elementary school students.
\end{abstract}

Keywords: Impact Sainspreneur, Student self-sufficiency, Student Creativity, elementary school

\section{Introduction}

National education based on Pancasila and the 1945 Constitution functions to develop capabilities and shape the character and civilization of a dignified nation in order to educate the life of a dignified nation in order to educate the nation's life. Explicitly, character education is contained in Law Number 20 of 2003 concerning the National Education System Chapter II Article 3, namely the development of the potential of students to become human beings who believe and fear God Almighty, have noble character, are healthy, knowledgeable, capable, creative., independent, and become a democratic and responsible citizen [1].

The Covid-19 pandemic has affected the education system in Indonesia [2]. Circular of the Secretary General of the Ministry of Education and Culture Number 36603/A.A5/OT/2020 dated March 15, 2020 contains important points regarding activity restrictions. in all lines, including school activities that simultaneously carry out learning from home since March 16, 2020 until today.

Based on a preliminary study conducted by researchers, it was found that many parents were not ready to accompany learning from home. Most parents finally choose a shortcut to solve the problem by providing internet-connected gadgets as a means to find answers to questions instantly. This behavior greatly affects the independence and creativity of students [2]. 
The independence and creativity of students can be built through ideal and fun learning activities. One of the educations that can support and facilitate the process of developing students' independence and creativity is science education or Natural Sciences, because elementary school science education in Indonesia is carried out by discovery and scientific inquiry by developing process skills and scientific attitudes through direct experience [3]. The educational process through direct experience will form quality human beings, in accordance with the opinion of Sari, et al which states that science education has a role as a means in creating quality future generations of the nation in facing challenges in the era of globalization [4].

Life skill education that can build the independence and creativity of students in science education, and entrepreneurship can be called sciencepreneurs. For implementing science education, teachers need to design and implement good teaching and learning strategies, namely a learning process that is organized interactively, inspiring, fun, and challenging, to motivate students to participate actively and be eager to be the best [5].

The application of sciencepreneur education requires a project as a means for students to produce products [6]. The project that is easiest to do and close to the environment of students is an farming project. A farming project that is suitable for school conditions with limited land is to use the urban farming technique.

Application of sciencepreneur education with urban farming techniques In the science subject, it aims to make the learning process more applicable, namely by providing students directly in designing and developing products through scientific concepts so that they are economically valuable and have an environmental insight which is helpful to equip students to become intellectually and financially powerful human solid beings in the future $[6]$.

Allah says in the Qur'an Surat An-Nisa: 9, "And fear Allah those who should leave behind them weak children, whom they worry about (their welfare)." In this verse, Allah emphasizes the importance of providing knowledge and skills to prepare a strong, independent, and prosperous generation in the future.

Rasyid expressed his opinion that investment in the future of a nation lies in the field of education [7]. This opinion was corroborated by Bailey et al., who stated firmly that the growth and income of a country were strongly influenced by the contribution and role of education [8].

The right strategy to answer these challenges is the application of entrepreneur science education. Ideal and fun learning is needed to realize optimal education. So the application of sciencepreneur education in science subjects is one of the right solutions to build the independence and creativity of students in elementary schools.

\section{Research Methods}

This research is a systematic review research. The data taken in this study is secondary data. Secondary data is data taken not from direct observers but the results of research by previous researchers. The data collection method used in this research is the documentation method. The documentation method is a systematic data collection procedure for reviewing both printed and electronic documents [9]. The documentation method is a data collection method by finding or extracting data from literature related to what is meant in the problem formulation. The data analysis used in this research is bibliographic annotation analysis. Annotation indicates a simple conclusion from an article, book, journal, or some other written source [10] 


\section{Results and Discussion}

The relationship between science and science learning in elementary schools is in the form of a learning process that utilizes scientific understanding to produce innovative, helpful work, and develop students' life skills. This learning program can also be called an effort to establish a science-based entrepreneurial spirit (Sciencepreneurship). With this spirit, students are expected to have a scientific attitude, be motivated to compete science, and have aspirations for a career or entrepreneurship by utilizing science knowledge [6].

The application of sciencepreneurship in science learning aims to build independence and creativity of students by utilizing science in everyday life and developing it to obtain a prosperous life in the future [6][10]. To achieve this goal, students must be given a stimulus through farming practices with urban farming techniques. Urban farming techniques have been used in learning as an applied learning model [11]. The learning concept that should be applied to facilitate understanding for children is student base learning through the direct practice of making simple applied technology in agriculture and creative industries, are packaged with a game system.

According to Ljubimova et al., self-sufficiency in learning is a learning activity that takes place more driven by own will, own choice, and own responsibility from education [12]. Affective aspects are characteristics of creativity that are more related to a person's attitudes and feelings which are characterized by certain feelings [13]; creativity, is a person's ability to think divergent and able to create something. New based on his thinking, interaction with the environment, and experiences obtained during his life.

The application of a sciencepreneur in science learning aims to build the independence and creativity of students by utilizing science in everyday life and developing it to gain prosperity in life in the future [6]. To achieve this goal, students must be given a stimulus through the practice of farming with urban farming techniques. Urban farming techniques have been used in learning as an applicative learning model. The learning concept that should be applied to facilitate understanding for students is student base learning through direct practice of making simple applied technology in agriculture and creative industries packaged with a game system [11]. Each student understands and understands and increases their knowledge in the field of agricultural technology [14].

The learning process carried out by students through gardening activities will build their independence and creativity, which is characterized by the following characteristics: behave independently, confidently, disciplined, have the initiative to learn, be responsible, and control themselves [15]. Creative students have the characteristics of fluent thinking, flexible thinking, originality of thinking, and elaboration [16].

\section{Conclusion}

Based on the background of the problem and the results of the literature study presented, it can be concluded that the application of sciencepreneur with urban farming techniques affects increasing the character of self-sufficiency and creativity of students in elementary schools. The author hopes this paper can be helpful an alternative study for teachers and related parties in building the self-sufficiency and creativity of students in elementary schools. 


\section{References}

[1] Sudaryono S, Aryani IK. School Policy in Improving Discipline Character of Elementary School Students. Dinamika Jurnal Ilmiah Pendidikan Dasar. 2021 Sep 22;13(2):101-3.

[2] Amalia RR, Anggoro S, Eka KI. Identification of Teachers and Students' Readiness to ELearning Implementation. JOURNAL OF TEACHING AND LEARNING IN ELEMENTARY EDUCATION (JTLEE); 4(2):170-9.

[3] Desstya A, Novitasari II, Razak AF, Sudrajat KS. Refleksi pendidikan IPA sekolah dasar di Indonesia (relevansi model pendidikan Paulo Freire dengan pendidikan IPA di sekolah dasar). Profesi Pendidikan Dasar. 2017 Jun 13;4(1):1-1.

[4] Sari DN, Rusilowati A, Nuswowati M. Pengaruh pembelajaran berbasis proyek terhadap kemampuan literasi sains siswa. PSEJ (Pancasakti Science Education Journal). 2017 Oct 31;2(2):114-24.

[5] Barlian I. Begitu Pentingkah Strategi Belajar Mengajar Bagi Guru?. InForum Sosial 2013 (Vol. 6, No. 01, pp. 241-246). Jurusan Pendidikan Ilmu Pengetahuan Sosial Fakultas Keguruan Dan Ilmu Pendidikan Universitas Sriwijaya.Coombs, Phillip Hall. (1968). The World Educational Crisis. Oxford University Press.

[6] Joham T. Barriers and ernablers to sciencepreneurship in Austria-an empirical analysis (Doctoral dissertation, Wien).

[7] Rasyid H. Membangun generasi melalui pendidikan sebagai investasi masa depan. Jurnal Pendidikan Anak. 2015 Jun 18;4(1).

[8] Bailey R, Hillman C, Arent S, Petitpas A. Physical activity: an underestimated investment in human capital?. Journal of physical activity and health. 2013 Mar 1;10(3):289-308.

[9] Bowen GA. Document analysis as a qualitative research method. Qualitative research journal. 2009 Aug 3.

[10] Arshad NI, Anggoro S, Abidin AI, Sugathan SK, Aszemi NM, Ramesh JR, Hawanti S. Technological Culturation on e-Government Sustainability among the Rural Communities in Malaysia. Arsyillah BT, Muhid A. Pendidikan Multikultural Dalam Membentuk Karakter Pemuda Di Perguruan Tinggi. Al-Fikr: Jurnal Pendidikan Islam. 2020 Aug 1;6(1):17-26.

[11] Sonti NF, Campbell LK, Johnson ML, Daftary-Steel S. Long-term outcomes of an urban farming internship program. Journal of Experiential Education. 2016 Sep;39(3):269-87.

[12] Ljubimova EM, Galimullina EZ, Ibatullin RR. The Development of University Students' Self-Sufficiency Based on Interactive Technologies by Their Immersion in the Professional Activity. International Education Studies. 2015;8(4):192-9.

[13] Asrori M. Psikologi Remaja: Perkembangan Peserta Didik. Jakarta: PT Bumi Aksara. 2017.

[14] Thoriq A. EDUKASI TEKNOLOGI PERTANIAN UNTUK ANAK USIA DINI DI DESA CILAYUNG, KECAMATAN JATINANGOR. Dharmakarya. 2017;6(1).

[15] Hendriana, H., E.E. Rohaeti, dan U. Sumarmo. Hard Skills dan Soft Skills Matematik Siswa. Bandung: PT. Revika Aditama. 2017.

[16] Nur MG, Risnawita R. Gaya Belajar Kajian Teoritik. Yogyakarta: Pustaka Pelajar. 2014. 